\title{
Professional Ambitions, Political Inclinations, and Protein Problems: Conflict and Compromise in the BMA Nutrition Committee 1947-1950
}

\author{
MARK W BUFTON, DAVID F SMITH and VIRGINIA BERRIDGE*
}

\section{Introduction}

When the British Medical Association (BMA) set up a committee on nutrition in 1947, this was not the first time they had entered this field. In 1933, at a time of concern about the adequacy of the diets of the poor and unemployed, the Association had appointed a committee to enquire into the minimum cost of an adequate diet. This had been the subject of a report produced by the weekly magazine Week-End Review, ${ }^{1}$ which was part of a wider debate about whether sections of the population were underfed and suffering from malnutrition. At this time, there were growing demands for greater government intervention in the food system to ensure everyone obtained an adequate diet. ${ }^{2}$ According to Peter Bartrip, the BMA began to take an interest in this field because medical practitioners wanted to forestall being excluded from a burgeoning area of knowledge by the agricultural and educational lobbies. ${ }^{3}$ David Smith has examined the earlier BMA Nutrition Committee and its conflict with the Ministry of Health's Advisory Committee on Nutrition during 1933-4 over protein and energy standards. He showed that the standards published in 1934 after negotiations between representatives of the two sides may be seen as a compromise between competing experts who were agreed that failure to reach consensus would lead to renewed and damaging public and political controversy. ${ }^{4}$

The current paper analyses some of the interactions between a further set of experts convened by the BMA in a different context, leading to the publication of a report on nutrition in $1950 .^{5}$ In contrast to the situation in the $1930 \mathrm{~s}$, the second committee was

\footnotetext{
* Mark W Bufton, PhD, Wellcome Centre for Medical History, SHIPSS, Amory Building, Exeter University, Exeter, EX4 4RJ; David F Smith, PhD, University of Aberdeen, Department of History, Meston Walk, Old Aberdeen, Aberdeen AB24 3FX; Prof. Virginia Berridge, History Group, London School of Hygiene and Tropical Medicine, Keppel Street, London, WC1E 7HT.
}

The research for this article was conducted with the support of the Wellcome Trust, which the authors gratefully acknowledge. The authors would like to thank Jerry Morris and three anonymous referees for helpful comments and criticisms. The usual disclaimer applies.

\footnotetext{
1 'Hungry England inquiry: Report of Committee', Week-End Review, 1 April 1933, 7: 357-60.
}

\footnotetext{
${ }^{2}$ For an account of the debate, see $\mathrm{C}$ Webster, 'Healthy or hungry thirties?', Hist. Workshop, 1983, 13: 110-29.

${ }^{3} \mathrm{P}$ Bartrip, Themselves writ large: the British Medical Association 1832-1966, London, British Medical Journal, 1996, pp. 201-5.

${ }^{4} \mathrm{D}$ F Smith, 'The social construction of dietary standards: the British Medical Association-Ministry of Health Advisory Committee on Nutrition Report of 1934', in D Maurer and J Sobal (eds), Eating agendas: food and nutrition as social problems, New York, Aldine De Gruyter, 1995, pp. 279-303.

${ }^{5}$ British Medical Association, Report of the Committee on Nutrition, London, British Medical Association, 1950.
} 


\section{Mark W Bufton, David F Smith and Virginia Berridge}

formed at a time when the state's control of the food system was comprehensive, following measures introduced during the Second World War. However, a new controversy erupted about trends in the health, physique and working capacity of the population and their links to diet. The Labour government was now faced with calls to withdraw from the food system, which it was accused of mismanaging to the detriment of the health and enjoyment of the population. In August 1946, the Minister of Food, John Strachey, introduced bread rationing for the first time, and food supply problems worsened during $1947 .{ }^{6}$ It was these conditions that gave birth to the new BMA committee.

The 1950 report contained a comprehensive set of nutrient requirements that was adopted by the government's National Food Survey Committee. These figures were used to assess the results of the annual survey of domestic food consumption until 1970, when the BMA figures were replaced by the Department of Health and Social Security's Recommended intakes of nutrients for the United Kingdom. ${ }^{7}$ The level at which the requirement figures were set in 1950 therefore had a considerable bearing on the question of whether or not the population of the UK was adequately fed for about two decades.

This paper will investigate the process by which the most contentious of the 1950 figures were arrived at-those expressing the protein requirements. A dispute about protein requirements during 1949 will be analysed. It will be argued that the intervention that created this dispute may be understood in the light of the professional ambitions and political inclinations of the actors involved. The responses of others may be understood in similar terms, but the eventual achievement of an agreed formula, as in 1934, reflected a common desire to avoid further controversy and also to meet deadlines for the completion of the report. This paper therefore provides an additional example that enhances historical understanding of how controversy can arise and be resolved in the preparation of reports by expert committees on nutrition. ${ }^{8}$

\section{The Decision to Establish the BMA Nutrition Committee, 1947}

During 1947, the growing public debate over the fairness of, responsibility for, and effects of the food situation, was mirrored by editorials, articles and exchanges in medical

\footnotetext{
${ }^{6} \mathrm{~S}$ Cooper, 'Snoek Piquante', in M Sissons and P French (eds), Age of austerity, London, Hodder and Stoughton, 1963, pp. 35-54.

${ }^{7}$ Department of Health and Social Security, Recommended intakes of nutrients for the United Kingdom, Report on Public Health and Medical Subjects No. 120, London, HMSO, 1969. R Passmore, D F Hollingsworth, and J Robertson, 'Prescription for a better British diet', Br. med. J., 1979, i: $527-31$, p. 527.

${ }^{8}$ Several other studies have explored aspects of the history of protein requirements and their application, including $\mathrm{K} \mathrm{J}$ Carpenter, Protein and energy: a study of changing ideas in nutrition, Cambridge University Press, 1994; N Aronson, 'Nutrition as a social problem', Soc. Probl., 1982, 29: 474-87, and 'Social definitions of entitlement: food needs, 1885-1920', Media Cult. Soc., 1982,
}

\author{
4: 51-61; L M Barnett, “"Every man his own \\ physician": dietetic fads, 1890-1914', in H Kamminga \\ and A Cunningham (eds), The science and culture of \\ nutrition, 1840-1940, Amsterdam, Rodopi, 1995, \\ pp. 155-78, and idem, 'Fletcherism: the chew chew \\ fad of the Edwardian era', in D F Smith (ed.), \\ Nutrition in Britain: science, scientists and politics \\ in the twentieth century, London, Routledge, \\ 1997, pp. 6-28, and J Ruxin, 'The rise and fall of \\ the Protein Advisory Group', in D F Smith and \\ J Phillips (eds), Food, science, policy and regulation \\ in the twentieth century: international and comparative \\ perspectives, London, Routledge, 2000, pp. 151-66. \\ However, only the current paper, and Smith, \\ 'Social construction', op. cit., note 4 above, are \\ based on archival resources that allow the kind of \\ detailed analysis of the negotiation of standards \\ that is presented here.
}




\section{Conflict and Compromise in the BMA Nutrition Committee 1947-1950}

journals, including the British Medical Journal (BMJ). ${ }^{9}$ Ina Zweiniger-Bargielowska, in Austerity in Britain, includes an account of the debate about the nutritional adequacy of the British diet immediately preceding the establishment of the BMA Nutrition Committee. She draws attention to Dr Franklin Bicknell's article 'Dying England' in the May 1947 number of the independent weekly medical journal the Medical Press. She shows, for example, that Bicknell's arguments were deployed by Lord Woolton, the Conservative party chairman and wartime Minister of Food, in debates and speeches. ${ }^{10}$

Bicknell had co-authored a successful book, The vitamins in medicine, reviewing knowledge on the use of vitamins in clinical practice. ${ }^{11}$ His Medical Press article, however, was altogether different in character, and began with the statement "England is dying from starvation". He claimed that all the food available, rationed and unrationed, was insufficient for the needs of the population and that therefore, "everyone in England is suffering from prolonged chronic malnutrition". He remarked that a survey conducted in 1933 showed that unemployed men and their wives had been better off then than the general population was now, fourteen years later. After four-and-a-half pages of polemic, he ended with "Once we were a great, a prosperous, a happy nation: once we were well fed". ${ }^{12}$

The editorial in the same issue of Medical Press supported Bicknell's article and described it as a response to a grossly misleading paper on 'Rations and nutritional needs' which had appeared in the BMJ in April. The authors were the Ministry of Health experts Drs E R Bransby and H E Magee, who concluded that filling the gap between the food provided by rationed and controlled foods and requirements "should present no difficulty for the great mass of the population". ${ }^{13}$ But the BMJ, like the Medical Press, was also sceptical about Bransby and Magee's arguments, even suggesting that they were "out of touch with realities". The $B M J$ also claimed that the Ministry of Food was failing to reveal food consumption data that could give a more accurate view of the situation. ${ }^{14}$

Against this background, the idea of establishing a BMA Nutrition Committee appears to have arisen partly as a result of the BMA's public relations problems. The BMA Council's annual report 1946-7 observed that, in contrast to the negative press comments on the Association's opposition to the National Health Service (NHS), the Council's protests over food problems had been well received. One such issue concerned the Ministry of Food overriding doctors' prescriptions for extra rations for the disabled. ${ }^{15}$ At the time of the preparation of the annual report, however, BMA representatives were engaged in discussions with the Minister of Health with the aim of winning favourable conditions of employment under the NHS. In view of these negotiations, this was deemed a "period unsuitable for intensive medico-political publicity", and the public relations officer, John Pringle, was instructed to "develop long-term plans for encouraging a better understanding ... of the

\footnotetext{
${ }^{9}$ For some examples of editorials see $\mathrm{Br}$. med. J., 1945, ii: $573,852-4 ; 1946$, i: $840-1 ; 1947$, i: 534-5; 1947, ii: 422, 427-8, 458-9, 696-7; 1948, i: 398-9; 1948, ii: $716-8$.

${ }^{10}$ I Zweiniger-Bargielowska, Austerity in Britain: rationing, controls, and consumption, 1939-1955, New York, Oxford University Press, 2000, p. 221.

${ }^{11} \mathrm{~F}$ Bicknell and F Prescott, The vitamins in medicine, London, Heinemann Medical, 1942 (2nd ed. 1946).
}

\footnotetext{
${ }^{12}$ F Bicknell, 'Special article: dying England', Medical Press, 1947, 217: 381-5, pp. 381, 385.

13 'The hungry sheep...', Medical Press, 1947, 217: 372-3.

14 'Bread rationing and calories', Br. med.J., 1947, i: $534-5$.

15 'Food rations for invalids: correspondence between the Secretary of the BMA and the Ministry of Food', Br. med. J., 1947, i: 230-1.
} 


\section{Mark $W$ Bufton, David F Smith and Virginia Berridge}

work of the profession". ${ }^{16}$ The chairman of the Association's Science Committee, the child psychiatrist R G Gordon, was also looking for opportunities for such initiatives, ${ }^{17}$ and in these circumstances the proposal was made to appoint a special nutrition committee. The BMA Council approved the proposal at the end of October, and Gordon and H Guy Dain, chair of the Council, were authorized to decide on the committee's composition. Its remit was to "examine the whole question of nutrition in this country and prepare an authoritative report with particular reference to the adequacy or inadequacy of the wartime and post-war diet". ${ }^{18}$

It therefore appears, that, as in 1933, for the BMA the establishment of a nutrition committee provided an opportunity for intervening in a public debate and improving their public profile. But the remit in 1947 was much more comprehensive, and it was soon clear that it would be impossible for the unwieldy committee to compile a report within a few months, as in 1933. And, while there was no official involvement in 1933, in 1947-50 important roles were taken by representatives of government departments upon whom the committee was heavily dependent for data. It was in this context that the intervention of two young scientists led to a dispute over protein requirements, the focus of this paper.

\section{The Appointment and Proceedings of the Nutrition Committee}

The list of prospective members included the 76-year-old medical statesman, Lord Horder, who has been described as "the greatest clinician of his day" and as exuding "wisdom and humanity". ${ }^{19} \mathrm{He}$ had been medical adviser to the Minister of Food since 1941, a role depending less upon any expert knowledge of nutrition, than upon his reputation as a doctor. ${ }^{20}$ Horder was probably appointed to the BMA Nutrition Committee partly in the hope that his status would impress outsiders, and that he would help to maintain order on the committee. He was elected chair at the first meeting. ${ }^{21}$

Among the prospective members were Sir Jack Drummond, Dr Hugh M Sinclair and Dr David PCuthbertson, three scientists who were among the main actors in the dispute over protein requirements. The profile of these scientists was enhanced by the fact that three prominent nutrition scientists who were either employed by or closely associated with the Medical Research Council (MRC) declined to serve. ${ }^{22}$ However, Harriette Chick, vitamin

\footnotetext{
16 'Annual Report of Council', Supplement to the British Medical Journal, 19 April 1947, p. 82.

17 'Annual Representative Meeting', Supplement to the British Medical Journal, 2 Aug. 1947, p. 44.

${ }^{18}$ Proceedings of Council, 29 Oct. 1947, Supplement to the British Medical Journal, 8 Nov. 1947 , p. 105.

19 'Thomas Horder', Munk's Roll, ed. R R Trail, London, Royal College of Physicians, 1968, vol. 5, p. 199.

${ }^{20}$ This is not to say that Horder's clinical experience was not useful in this role. One of his tasks was to act as a representative of the Ministry of Food on the Special Diets Committee of the Medical Research Council which established
}

principles and heard appeals regarding exceptions to the rationing system for those suffering particular illnesses. See Public Record Office, London (hereafter PRO), FD 1/5311, Food rationing (Special diets) Advisory Committee, 1940, et seq.

${ }^{21}$ Archives and Manuscripts, Wellcome Library, London (hereafter Wellcome) SA/BMA/J.85, Minutes of Committee on Nutrition, 1 Dec. 1947.

${ }^{22}$ Wellcome, SA/BMA/J.85, Minutes of Committee on Nutrition, 1 Dec. 1947; SA/BMA/G.53, letter from L Harris to C Hill, 24 Nov. 1947. Harris, Platt and McCance probably declined the invitation to serve partly because of the long-established attitude of the MRC secretary, Edward Mellanby, towards the involvement of MRC-reliant personnel 


\section{Conflict and Compromise in the BMA Nutrition Committee 1947-1950}

pioneer and long-standing member of the MRC's Accessory Food Factors Committee, who had recently retired from her post at the Lister Institute, did join the committee. In addition, four members of, and one adviser to, the original 1933 BMA Nutrition Committee were nominated, as were seven others whose expertise covered school, public, and industrial health, paediatrics and general practice ${ }^{23}$ (see Table 1).

Drummond was former chief scientific adviser of the Ministry of Food. He had taken a post as chief scientist at Boots Pure Drugs Co. in 1945, but had been seconded back to the Ministry, where his successor was not appointed until the autumn of 1947 . He had already received a great deal of credit for the Ministry's wartime achievements in feeding Britain's population, ${ }^{24}$ and at the end of 1947 he had publicly opposed the views of Bicknell and defended the government's record (and therefore his own as chief scientific adviser at the Ministry of Food). ${ }^{25}$ Within the BMA Nutrition Committee he was sometimes treated as a "wise man" of nutrition science, someone who might be consulted with a view to settling a difference of opinion, and, as will be seen, he was expected to play this role in the protein dispute.

During the war, Sinclair had directed the Oxford Nutrition Survey, financed by the Rockefeller Foundation. He claimed that Oxford University had undertaken to establish a nutrition department when the Rockefeller funding ended but had reneged on the promise. When setting up the Survey, he also had declined to involve the MRC, offending the MRC secretary Edward Mellanby and effectively precluding this source of funds. Now, with modest Wellcome Trust funding, he was director of a make-shift human nutrition laboratory attached to the Churchill Hospital, Oxford. ${ }^{26}$

Cuthbertson had recently become director of the Rowett Research Institute, near Aberdeen, a facility that had been established during the 1910 s and early 1920 s, with government and private funding, to conduct research in animal nutrition. ${ }^{27}$ Drummond and Sinclair readily accepted appointment to the BMA Nutrition Committee while Cuthbertson declined to be a member. ${ }^{28}$ This was probably a result of pressure upon him to confine the attention of his Institute to the nutrition of animals of agricultural importance and not to become involved in the more politically contentious field of human nutrition as had his predecessor, John Boyd Orr. ${ }^{29}$ Nevertheless, he agreed to provide background advice if necessary.

in non-MRC nutrition activities, and partly because of their own views as to the proper work that they should undertake. See D F Smith, 'Nutrition science and the two world wars', in Smith, Nutrition in Britain, op. cit, note 8 above, pp. 142-66, on p. $157,160$.

${ }^{23}$ Wellcome, SA/BMA/J.85, Minutes of Committee on Nutrition, 1 Dec. 1947.

${ }^{24} \mathrm{~J}$ Burnett, Plenty and want: a social history of diet in England from 1815 to the present day, London, Nelson, 1966, p. 259.

25 'Diet and the nation's health: debate by the Hunterian Society', Br. med. J., 1947, ii: 882-4.

${ }^{26}$ Interview: H M Sinclair recorded by D F Smith, 13 Nov. 1979. The tape and transcript, and those of the other interviews referred to in these notes, are in the possession of David Smith. Much the same story that Sinclair related in interview about the failure of Oxford University to establish a Department of
Nutrition appears in M Gale and B B Lloyd (eds), Sinclair, London, McCarrison Society, 1990. The author of a recent biography, however, presents a more complex story. See J H Ewin, Fine wines and fish oil: the life of Hugh Macdonald Sinclair, New York, Oxford University Press, 2001, pp. 172-9.

${ }^{27} \mathrm{D}$ F Smith, 'The early institutional and scientific development of the Rowett Research Institute', in A Adam, D F Smith, and F Watson (eds), 'To the greit support and advancement of helth': papers on the history of medicine in Aberdeen, Aberdeen History of Medicine Publications, 1996, pp. 45-53.

${ }^{28}$ Wellcome, SA/BMA/G.53, letter from D Cuthbertson to C Hill, 19 Nov. 1947.

${ }^{29}$ Interview: D P Cuthbertson recorded by D F Smith, 1 Nov. 1979. On Orr's work in human nutrition in the late 1930 s, see D F Smith, 'The Carnegie Survey: background and intended impact', 


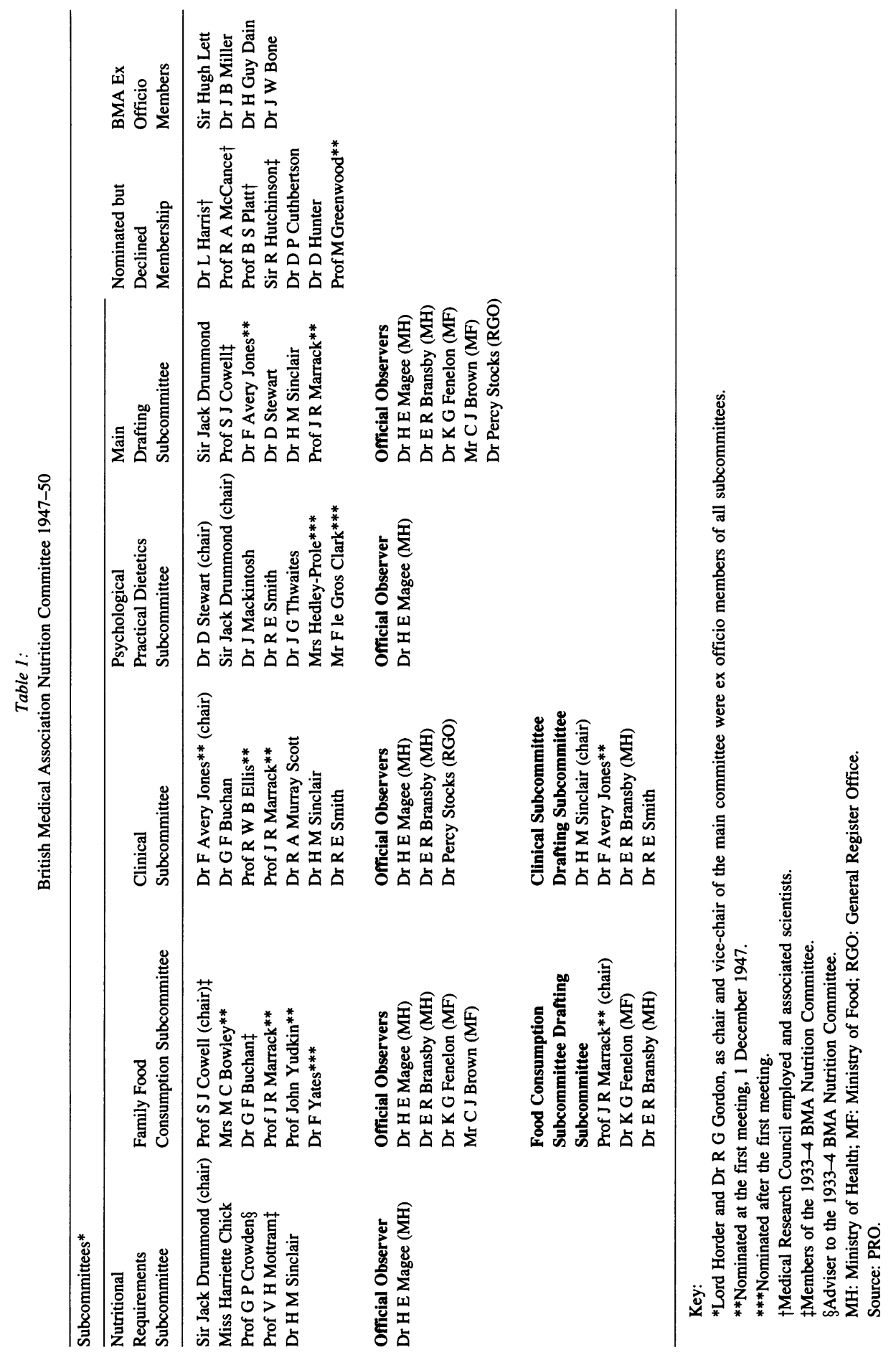




\section{Conflict and Compromise in the BMA Nutrition Committee 1947-1950}

Drummond and Sinclair both played key roles in the work of the Committee. At the first meeting four subcommittees were formed: on nutritional requirements, family food consumption, clinical aspects, and psychological and practical aspects of nutrition (see Table 1). Drummond became chair of the nutritional requirements subcommittee and a member of the psychological and practical aspects subcommittee. Sinclair was appointed to both the nutritional requirements and clinical subcommittees. ${ }^{30}$ Despite his decision not to become a member, Cuthbertson did contribute to the work of the Committee by preparing a memorandum and attending some meetings.

Since a number of people had declined to serve, and because of a desire to broaden the range of expertise, it was decided at the first meeting on 1 December 1947 to invite five additional people to join the committee. Four of these second-choice experts accepted the invitation, including John Yudkin, who had recently succeeded V H Mottram as professor of physiology at King's College of Household and Social Science. Here he was engaged in moves to establish a degree in nutrition, but was having difficulties in convincing the University of London authorities that nutrition was a respectable and viable university science degree subject. ${ }^{31}$ Yudkin was later one of the initiators of the protein dispute.

Other new members included J R Marrack, professor of chemical pathology at the London Hospital. Marrack had authored Food and planning, published by the left-wing publisher Victor Gollancz in 1942, and during 1947 he publicly defended the Labour government's record on food. ${ }^{32}$ He directed the Nutrition Society's "Bureau of Nutrition Surveys" from 1943 until early 1947, which aimed to standardize survey methods; another person appointed to the Committee after the initial nominations was Frederick le Gros Clark, who became a member of the subcommittee on psychological and practical aspects of nutrition. ${ }^{33}$ Clark had been a founder member and secretary of the left-wing Committee Against Malnutrition in the 1930s. He was now a recognized authority on food habits and had recently advocated the development of "food sociology".34

To provide statistical expertise, Frank Yates, statistician of the Rothamsted Experimental Station, was appointed to the food consumption subcommittee, after another more eminent statistician declined to serve. ${ }^{35}$ Yates had published (jointly with R A Fisher) two editions of Statistical tables for biological, agricultural and medical research since 1938, and the first edition of his Sampling methods for censuses and surveys was due for publication in $1949 .^{36}$ He was to become involved in the protein dispute, supporting the position taken by Yudkin.

in A Fenton (ed.) Order and disorder: the health implications of eating and drinking in the nineteenth and twentieth centuries, East Linton, Tuckwell Press in association with the European Ethnological Research Centre, 2000, pp. 64-80.

${ }^{30}$ Wellcome, SA/BMA/J.85, Minutes of Committee on Nutrition, 1 Dec. 1947.

${ }^{31}$ Interview: J Yudkin recorded by D F Smith, 27 Nov. 1979.

32 J R Marrack, Food and planning, London, Gollancz, 1942; J R Marrack, 'Food then and now', The Times, 2 May 1947, 5e.

${ }^{33}$ Wellcome, SA/BMA/G.61 Letter from A Macrae to F le Gros Clark, 19 Jan. 1948.

${ }^{34}$ D F Smith, 'The discourse of scientific knowledge of nutrition and dietary change in the twentieth century', in A Murcott (ed.), The nation's diet: the social science of food choice, London, Addison-Wesley, Longman, 1998, pp. 311-31, on pp. 319-22.

${ }^{35}$ Wellcome, SA/BMA/G.65, letter from F Yates to A Macrae, 24 Feb. 1948. The statistician who declined the invitation was Professor Major Greenwood of the London School of Hygiene and Tropical Medicine. SA/BMA/G.60, letter from M Greenwood to C Hill, 5 Dec. 1947.

${ }^{36} \mathrm{R}$ A Fisher and F Yates, Statistical tables for biological, agricultural and medical research, London, Oliver and Boyd, 1938, 1945, 1948; F Yates, Sampling methods for censuses and surveys, London, C Griffin, 1949. 


\section{Mark W Bufton, David F Smith and Virginia Berridge}

By the time of the first meeting, the Ministry of Health had supplied an observer, H E Magee, who attended all four subcommittees, and later appointed E R Bransby as an additional observer. Bransby and Magee were the authors of the paper attacked by Bicknell. The Ministry of Food appointed two observers including K G Fenelon, director of statistics and intelligence, who attended the food consumption subcommittee, and the General Register Office also appointed an observer. ${ }^{37}$ With the completion of the appointments of subcommittees and observers, the BMA had effectively sub-divided the whole field of nutrition and assigned expertise in particular areas as illustrated in Table 1. As the Table details, two of the subcommittees appointed drafting subcommittees for preparing their section of the report and a further drafting committee of the main committee was also established. Yudkin and Yates were not members of the nutritional requirements subcommittee, the findings of which they challenged, nor any of the drafting subcommittees. Their intervention on the question of protein requirements, when it came in April 1949, was at a meeting of the main committee when a complete draft of the Committee's report was under discussion.

\section{The Emergence of a Dispute over Protein Requirements}

When the nutritional requirements subcommittee first met in January 1948, the discussion began as a critical examination of figures published by the American National Research Council in 1945. Soon, however, the subcommittee focused on the figures used by Sinclair in the Oxford Nutrition Survey, which Sinclair intended to publish independently. As regards most nutrients, it was Sinclair's standards, with some small adjustments, which were the basis for the scales adopted in the final BMA Nutrition Report. ${ }^{38}$ There are several factors that may account for the relative ease with which it proved possible to agree on figures as regards mineral and vitamin requirements. These included the participation of Harriette Chick, whose long-term involvement in this field was unparalleled. With regard to some nutrients, new data had recently become available in view of the exploitation by the Accessory Food Factors Committee of war-time research opportunities. ${ }^{39}$

As regards calories, one point at issue concerned the best way to express requirements according to work groups. But divergences of opinion in this area were effectively overcome when it was agreed at the reconvened full committee in December 1948 that the report should include a note stating that there was a need for research on the classification of occupations according to energy expenditure. ${ }^{40}$ The call for more research also suited the official representatives, as the government had been facing demands for increased rations for certain classes of worker. ${ }^{41}$ With regard to protein, however, a different path was adopted, as will be explained shortly.

\footnotetext{
${ }^{37}$ Wellcome, SA/BMA/J.85, Minutes of Committee on Nutrition, 1 Dec. 1947; SA/BMA/J.87, Minutes of Committee on Nutrition, 14 Dec.1948.

${ }^{38}$ Wellcome, SA/BMA/J.85, Minutes of Subcommittee on Nutritional Requirements, 5 Jan., 6 Feb., 19 March, 7 May, 15 June 1948.

${ }^{39} \mathrm{E} \mathrm{M}$ Hume and H A Krebs, 'Vitamin A requirements of human adults: an experimental study of vitamin A deprivation in man', Medical Research
}

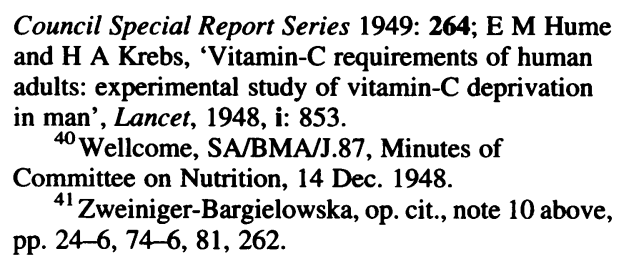
and H A Krebs, 'Vitamin-C requirements of human adults: experimental study of vitamin-C deprivation in man', Lancet, 1948, i: 853.

${ }^{40}$ Wellcome, SA/BMA/J.87, Minutes of Committee on Nutrition, 14 Dec. 1948.

${ }^{41}$ Zweiniger-Bargielowska, op. cit., note 10 above, pp. 24-6, 74-6, 81, 262. 


\section{Conflict and Compromise in the BMA Nutrition Committee 1947-1950}

The subcommittee on food consumption, of which Yudkin and Yates were members, held four meetings before establishing a drafting subcommittee, to which they were not appointed. The subcommittee had very quickly become dependent upon government data, especially from the surveys of the Ministry of Food's statistics and intelligence division, of which Fenelon was director. In view of their control of the data, the officials were much more than "observers". They also made up half the membership of the drafting subcommittee and took much of the responsibility for the preparation of the draft report. ${ }^{42}$ There is no evidence of Yates being able to deploy his statistical expertise, for which he had been supposedly appointed, and no evidence of Yudkin making significant contributions to the work of the subcommittee.

When the full Committee met in December 1948, it discussed reports of all four subcommittees. During this meeting there were signs of a desire by Yudkin to intervene in areas beyond the business of his own subcommittee. He spoke up during the discussion of the report on "practical dietetics". Yudkin expressed the view that this tended to echo the "complaints of the well-to-do section of the community and ignored the fact that the great bulk of the population was in a better position in respect of food supplies than ever before". Marrack and le Gros Clark sympathized with this view, but the general feeling was that there was dissatisfaction among all social classes that should not be ignored. The alignment of Yudkin with two members with known left-wing associations, in defending the progress that had been made in sharing food supplies among the population, indicates his egalitarian sentiments, which were also to become evident during the protein dispute. At the December 1948 meeting, a further drafting committee was established to prepare a final report, consisting of the chairs of the four subcommittees and their drafting subcommittees, and representatives of the three government departments. ${ }^{43}$ In April 1949, a complete draft report was placed before the main committee. Here the peaceful proceedings of the past fifteen months were disrupted when the section on protein requirements was challenged. $^{44}$

The contents of the draft protein paragraphs had been shaped by discussions beginning at the first meeting of the nutritional requirements subcommittee in January 1948. Here Drummond had observed that the question of protein requirements was unsettled because it was "impossible to arrive at exact conclusions until more was known about the individual amino-acid requirements". Chick commented that there was "no scientific basis for the supposed superiority of animal protein" but Drummond suggested that in practice there was a "psychological minimum" of such protein, or "a point below which it was impossible for the housewife to produce tolerable meals". ${ }^{45}$ This view reflected the practical approach that Drummond had adopted in connection with his work at the Ministry of Food.

At the second meeting of the subcommittee, despite the pressure he was under to confine his activities to the nutrition of farm animals, Cuthbertson was in attendance for a further discussion of protein requirements. Isabella Leitch, director of the Commonwealth Bureau

\footnotetext{
${ }^{42}$ Wellcome, SA/BMA/G.61, E R Bransby and J R Marrack to A Macrae, 23 Oct. 1948.

${ }^{43}$ Wellcome, SA/BMA/J.87, Minutes of Committee on Nutrition, 14 Dec. 1948.
}

\footnotetext{
${ }^{44}$ Wellcome, SA/BMA/J.87, Minutes of Committee on Nutrition 14 April 1949.

${ }^{45}$ Wellcome, SA/BMA/J.84, Minute of subcommittee on nutritional requirements, 5 Jan. 1948.
} 


\section{Mark W Bufton, David F Smith and Virginia Berridge}

of Animal Nutrition, which was based at the Rowett Institute and authorized to cover both human and animal nutrition, accompanied him. ${ }^{46}$ At this stage Cuthbertson argued that, although there was no "theoretical advantage" to "putting out figures for animal protein", it was a fact that "among the more virile races, 60 to 65 percent of the protein consumed was of animal origin". He thought it best to recommend that two-thirds of protein in the diet should be of animal origin. As a way forward, it was decided to ask Cuthbertson to prepare a paper on protein requirements for the next meeting. ${ }^{47}$

Cuthbertson's background was in physiological chemistry and before the war he had studied the effects of muscular work, energy, and carbohydrate and fat intakes upon protein metabolism in human subjects, using the classic techniques of this field ("balance" experiments measuring the body's inputs and outputs). It was probably this experience that made him, in the subcommittee's view, an appropriate authority to consult. In his memorandum, however, he soon made it clear that he thought that the experimental evidence had little to contribute to the practical problem of dietary requirements. Cuthbertson first proposed that for protein the word "allowance" should be substituted for "requirements" as "no satisfying data exist to provide us with a real knowledge of true requirements". On the question of animal protein, the emphasis of the memorandum was rather different to that expressed in his comments at the previous meeting. The document drew attention to the "attractive flavour and culinary properties of animal protein" but observed that it was possible to live and reproduce with no or little dietary animal protein. ${ }^{48}$ The subcommittee now followed the line Chick had suggested and effectively disposed of any attempt to define an allowance for animal protein along the lines of those adopted by the 1933 BMA Nutrition Committee and the Advisory Committee on Nutrition in their earlier reports. The Advisory Committee on Nutrition had suggested $37 \mathrm{~g}$ while the 1933 BMA Nutrition Committee suggested $50 \mathrm{~g}$ of "first class protein" as the average requirement of protein per man per day. ${ }^{49}$

Cuthbertson reviewed approaches to the study of protein requirements that employed feeding experiments. These involved either nitrogen balance experiments or tests of physiological efficiency and the maintenance of health on low-protein diets, or the estimation of endogenous nitrogen excretion and the nitrogen required for growth and milk production. But the calculations and safety margins applied to the data generated by such experiments were influenced by a desire to bring the requirements up to the level of customary intakes. These points made, he suggested that rather than rely upon experiments, "it is much safer to view our allowance in terms of the dietary habits of the best nourished section of the community and to pay particular regard to the proportion of the total calories derived from protein. This gives us a measure of protein allowance which is safe".50

Having introduced the idea of the protein allowance as a percentage of calories, the memorandum admitted that since people tended to eat more or less of a mixed diet to satisfy

\footnotetext{
${ }^{46}$ A M Thomson, 'Obituary notice Isabella Leitch 1890-1980', Br. J. Nutrition, 1981, 45: 1-4.

${ }^{47}$ Wellcome, SA/BMA/J.84, Minute of subcommittee on nutritional requirements, 6 Feb. 1948.

${ }^{48}$ British Medical Association Archive (hereafter BMAA) B/253/1/1, Minutes of Nutrition Committee, 1947-8. D Cuthbertson, 'Protein allowances for
}

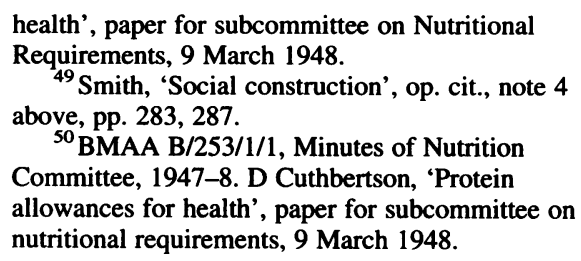
nutritional requirements, 9 March 1948. 


\section{Conflict and Compromise in the BMA Nutrition Committee 1947-1950}

their energy needs, those with high energy expenditures might be thought to be taking too much protein. However, it was considered that there was little hope of altering the quantity of protein consumed by the "natural selection" of diets. Before 1939, protein intakes had amounted to 10-14 per cent of calories, while a more recent study showed the protein intake of "middle-class" children was in the range 11-14 per cent. Protein intakes had risen slightly since fats and sugar had been subject to controls.

When Cuthbertson submitted his memorandum, he observed that it might not be "that which the committee had in mind", 51 probably because of the rejection of experimental evidence. But the strategy he adopted was not new. The idea that dietary survey data were more reliable than experimental evidence had been previously articulated by Cuthbertson's teacher, Edward Cathcart, regius professor of physiology at Glasgow University 1928-47. The subcommittee adopted the approach suggested by Cuthbertson and the draft report placed before the full committee in December 1948 and April 1949 used a formula along the lines he advocated:

$\ldots 14$ per cent of the calories in the form of protein of a mixed diet is sufficient for all nutritional needs. The Committee accepts this conclusion in so far as it concerns the food of pregnant and nursing women, infants, children and adolescents, but is of the opinion that after the age of 21 a smaller proportion of mixed protein is compatible with good health. The committee recommends, therefore, that the diet of adults, other than pregnant and nursing women, should provide not less protein than an amount representing $10 \%$ of the energy allowance. ${ }^{52}$

Despite the earlier apparent consensus, controversy about protein requirements erupted at the April 1949 meeting, following the intervention of Yudkin and Yates, as will be seen shortly. According to the minutes, Yudkin also made two other interventions.

Early in the meeting Yudkin raised the question of including a call for the creation of a "Nutrition Council" in the report. This would "keep a continuous check on the nutritional state of the population and undertake a co-ordinated series of investigations into the many and important nutrition questions which still remained unsolved". 53 This was a revival of a campaign Yudkin had begun in 1942, when there had been a debate in The Times after he had published an anonymous article in that newspaper calling for the formation of a Nutrition Council. This preceded the creation of a Bureau of Nutrition Surveys of the Nutrition Society directed by Marrack. ${ }^{54}$ At the BMA Committee meeting, Marrack spoke in support of Yudkin's suggestion.

Yudkin also remarked on the section of the report on psychological and practical aspects of nutrition. He suggested that it gave the impression that the Committee wanted the end of rationing as soon as possible, "regardless of whether sufficient food was available to ensure an adequate supply for everyone". He wanted to make it clear that the Committee wished to see an improvement in the food situation not only in Britain, but also throughout the world,

\footnotetext{
${ }^{51}$ BMAA B/253/1/1, Minutes of Nutrition Committee, 1947-8. Covering letter from D Cuthbertson, 'Protein allowances for health', paper for subcommittee on nutritional requirements, 9 March 1948.

52 BMAA B/253/1/2, Minutes of Nutrition Committee, 1948-9: Draft report of the Committee
}

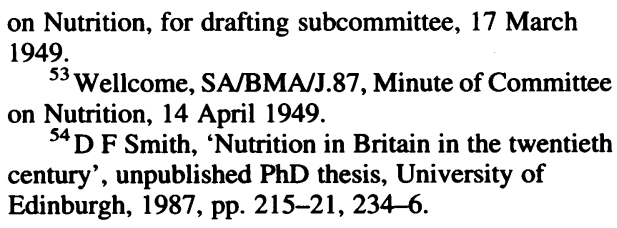

${ }^{54} \mathrm{D}$ F Smith, 'Nutrition in Britain in the twentieth century', unpublished $\mathrm{PhD}$ thesis, University of Edinburgh, 1987, pp. 215-21, 234-6. 


\section{Mark W Bufton, David F Smith and Virginia Berridge}

so that rationing would be unnecessary. ${ }^{55}$ Once again, this articulated an egalitarian sentiment, also seen in Yudkin's remarks at the previous meeting.

Regarding the beginning of the protein dispute, few details of the arguments were recorded and it is only from documents prepared later that the nature of Yudkin's and Yates' arguments become clear. The minutes only record that Yates criticized the paragraphs on protein and that Yudkin suggested that the evidence for the figures used should be given. Yudkin claimed, "the assessment of protein requirements in terms of the percentage of calories derived from protein was a departure from customary practice". Drummond was absent from the meeting, but it was decided to invite him to expand the paragraphs on protein in order to take account of the discussion that had taken place. ${ }^{56}$

\section{Conflict and Consensus}

It was almost a month before Angus Macrae, the BMA assistant secretary, began to sort out the protein problem. He told Drummond that his absence from the meeting had been "disastrous". Macrae was not sure that he had grasped the point of all that was said but was "very annoyed about the whole business". Although the Committee was not working with the same sense of urgency as the BMA/Advisory Committee on Nutrition conferences of 1934, its work could not be allowed to continue indefinitely, and Macrae was alarmed that his hope of getting the report into print for the May meeting of the Council had been dashed. ${ }^{57}$ Macrae told Horder that he had taken "a long time to recover my equanimity after that dreadful seven hours meeting". He was especially annoyed about the attack on the protein paragraphs because they had been accepted at the December 1948 meeting. ${ }^{58}$

Macrae now asked Yudkin and Yates to write to Drummond to explain their position. Yudkin told Drummond that he and Yates were "concerned first about the general principle of relating requirements of protein to dietary habits", which he thought might lead to "trouble". Since better-off people ate more proteins than those less well-off, he asked, "Is it not possible that it will be argued that we should aim at a consumption for all groups equal to that of the highest group?" Secondly, if protein requirements were expressed as a percentage of calorie intake this would contradict the generally held view that "the protein requirements of a normal adult are independent of calories". After a campaign for special treatment, extra allowances of animal foods had been made available for coal miners in $1946,{ }^{59}$ but this had been said to be based upon dietary rather than nutritional considerations and was justified by the particular working conditions in mining. The Labour government could be faced with further political difficulties, and discontent among their traditional supporters, if the BMA Committee were now to "definitely relate proteins to Calories". Yudkin envisaged "an increased demand from various groups of workers for increases in meat and cheese rations". In Yudkin's view, the more usual and acceptable way of expressing protein requirements was to give a certain weight of protein needed per unit of body

\footnotetext{
${ }^{55}$ Wellcome, SA/BMA/J.87, Minute of Committee on Nutrition, 14 April 1949.

${ }^{56}$ Ibid.

${ }^{57}$ Wellcome, SA/BMA/G.59, letter from A Macrae to J Drummond, 12 May 1949.
}

\footnotetext{
${ }^{58}$ Wellcome, SA/BMA/G.62, letter from A Macrae to Lord Horder, 12 May 1949.

${ }^{59}$ Zweiniger-Bargielowska, op. cit., note 10 above, pp. 24-6, 74-6, 81, 262.
} 


\section{Conflict and Compromise in the BMA Nutrition Committee 1947-1950}

weight. If the Committee was to depart from this approach a detailed explanation of the reasons should be given. ${ }^{60}$

Yates' concerns were similar, but he emphasized the consequence of the "percentage of calories" approach for those with a low energy expenditure:

... an adult male with a requirement of 2200 calories ... of which $10 \%$ is in the form of protein will have an intake of ...54 gm. of protein per day. Whereas an adult with an energy intake of 4500 calories ... per day will have an intake of $110 \mathrm{gm}$. per day. While the latter intake ... may be considered adequate, the former will be regarded as definitely low. No adjustment of the percentage will overcome this difficulty ... ${ }^{61}$

Yates' conclusions were based upon a commonly quoted estimate of adult protein requirements in the region of $100 \mathrm{~g}$ of protein per day. In this light, Yates thought, "it would be dangerous - and not prudent-to view the matter in the light of the dietary habits of the community without having careful regard to the individuals in that community". He favoured the reinstatement of some definite allowance along the lines he had indicated. He further argued that the existing paragraphs gave a misleading impression as they did not take into account the fact that some plant proteins do not provide "an even distribution of amino acids". He agreed that it was probably true that animal protein had no special intrinsic value, but it was nevertheless clear that the more even distribution of amino-acids in animal proteins enhanced their importance. ${ }^{62}$

Drummond does not seem to have seen any practical problems with the draft protein paragraphs, despite the anxieties of Yudkin and Yates. He was probably well satisfied with the overall line of the draft report, which concluded that the diet and health of the population had been well-maintained during and following the war, thereby providing little ammunition for the likes of Bicknell. ${ }^{63} \mathrm{He}$ told Yudkin that he was "seriously disturbed" that he and Yates should raise objections at so late a stage. He intimated that he was "not much impressed" by their arguments, but would consult the subcommittee on nutritional requirements about the matter. ${ }^{64}$ Similarly, Drummond told Macrae that he thought Yates and Yudkin were "making a very large mound out of a very small mole-hill". But there was little possibility of "a satisfactory settlement of the dispute" without calling an emergency subcommittee meeting, which would be "very tiresome"-and inviting Cuthbertson to attend. ${ }^{65}$ Drummond later told Macrae that although he was "still very angry" he thought that Yudkin and Yates should also be invited. ${ }^{66}$

Drummond sought the advice of Sinclair, who thought the best alternative would be to "tell Yudkin and Yates to go to hell were that not a little uncharitable to the present

\footnotetext{
${ }^{60}$ Wellcome, SA/BMA/G.59, letter from J Yudkin to J Drummond, 14 May 1949.

${ }^{61}$ Wellcome, SA/BMA/G.65, letter from F Yates to J Drummond, 17 May 1949.

${ }^{62}$ Ibid.

${ }^{63}$ The Committee's bland findings were disappointing to the BMA's deputy secretary, Angus Macrae, in view of the amount of work involved in arriving at them. With reference to this outcome he commented, "Parturiunt montes, nascetur ridiculus mus", meaning "the mountains are in travail, an absurd mouse will be born". Wellcome, SA/BMA/
}

G.65, letter from A Macrae to $\mathbf{H}$ Sinclair of 9 Aug. 1949. The proverb is to be found in Horace's Ars poetica, 139. Definition of this Latin phrase was taken from The Chambers Dictionary, Edinburgh, Chambers Harrap Publishers Ltd, 2000, p. 1976.

${ }^{64}$ Wellcome, SA/BMA/G.59, letter from J Drummond to J Yudkin, 16 May 1949.

${ }^{65}$ Wellcome, SA/BMA/G.59, letter from J Drummond to A Macrae, 19 May 1949.

${ }^{66}$ Wellcome, SA/BMA/G.59, letter from J Drummond to A Macrae, 24 May 1949. 


\section{Mark W Bufton, David F Smith and Virginia Berridge}

inmates". Nevertheless, he prepared a paragraph to substitute for the one in dispute, "bits of which might please everyone". He explained: "it has a large slice of Cuthbertson and an odour of Yudkin". ${ }^{67}$ Sinclair proposed to add a reference to the years when the range of protein intakes mentioned appeared to have been satisfactory, and to add some remarks about animal protein intakes as follows:

Before the war and between the years 1940 and 1946, when growth and health were well sustained, the total energy derived from protein generally lay between 10 and 14 per cent.; and before 1939, whenever economic circumstance permitted, the intake of protein of animal origin was raised to the region of 60 per cent. of the total protein.

The figures of 10 per cent of energy for adults other than pregnant and nursing women, and 14 per cent for the latter and infants, children and adolescents remained, but it was also pointed out that "if hard work is done the protein intake will in fact be increased, but the need for such an increase has not been established." 68

The emergency meeting took place on the 7 June 1949 and Cuthbertson, Yudkin, and Yates were present. After considerable discussion it was decided that the report should make reference to the widely used figures for adults in terms of grams per kilogram of body weight. Macrae commented to Horder that this was agreed to "placate Yates and Yudkin", but that a remark about these figures having no scientific basis would be included, and that the recommendations would be substantially in the form in which they were before. ${ }^{69}$ It was agreed that Drummond would redraft the protein section and that the new version would be submitted to members of the subcommittee and to Cuthbertson, Yates and Yudkin for comments. It was decided to leave Cuthbertson and Sinclair to decide what figure for protein would be recommended as a percentage of total energy allowance for the normal adult. ${ }^{70}$

There is no evidence that Drummond's re-draft caused any further difficulties, but a key paragraph, as published, was effectively a dismissal of one of the main planks of Yudkin's and Yates' arguments. The paragraph explained that in the opinion of the Committee it was undesirable for "a misleading impression of precision and finality" to be given by "endorsing such figures as the widely used 1 gram of protein per kilogram of adult body weight". The Committee therefore decided to employ

$\ldots$ an alternative approach ... by considering protein intakes in relation to calorie intakes. At first sight, this may appear a retrograde step, but it will be found to have much to recommend it if it is considered in the light of the lack of precise knowledge of human protein requirements, the quality of the mixture of proteins provided by the food and eaten by the people of the United Kingdom, and the record of food consumption in its relation to national health and welfare during the past ten years. $^{71}$

In contrast, the achievement of agreement between Sinclair and Cuthbertson did prove difficult. The issue at stake was the figure which would appear as the Committee's recommended allowance for the bulk of the population. Cuthbertson thought that "if our dietary

\footnotetext{
${ }^{67}$ Wellcome, SA/BMA/G.65, letter from H Sinclair to J Drummond, 24 May 1949.

${ }^{68}$ Wellcome, SA/BMA/G.59, 'Dr Sinclair's revised draft of para. 42', 24 May 1949.

${ }^{69}$ Wellcome, SA/BMA/G.62, letter from A Macrae to Lord Horder, 14 June 1949.
} 
habits continue as they do" then the figure should be $12 \mathrm{~g}$, but "if we revert to the prewar diet; 11 would be better". These remarks anticipated the drop in protein intakes that could be expected once the restrictions on fats and sugars were lifted. ${ }^{72}$ Sinclair, in contrast, told Drummond that since they were "stating a minimum figure for ordinary adults ('the diet should provide not less protein than')" then the figure of 10 per cent should be used. This, he calculated, would "give a moderately active man or woman (at 3,000 and 2,500 Cal.) more than the classical $1 \mathrm{~g} . / \mathrm{kg}$. body-weight". On the other hand, if " 12 " was used this would give "even more than the per caput protein consumption of urban working class families as recorded in the last two Family Food Surveys of the Ministry of Food". ${ }^{73}$ Sinclair later intimated that "Since Cuthbertson is prepared to admit $11 \%$ as a compromise" they should settle on that figure deleting the words "not less protein than" in the sentence "the Committee recommends that the diet should provide an amount representing not less protein than $11 \%$ of the energy allowance". Apologizing for being "troublesome", he explained:

... my difficulty in this; If the mean protein consumption of the adult population is about $11 \%$ it is reasonable to suppose that half of them are eating more and half less than this figure ... The Bicknells [emphasis added] and others will have a hue and cry again about half the population being starved of protein ... Therefore if the Committee should put as a minimum figure one that is about the mean of working class families at the present time, I should like to put a foot-note to say that I disagree with the figure 11 and would prefer 10; but if we can delete the words "not less protein than" and simply put a recommendation I certainly agree with the figure of $11 .^{74}$

Macrae reported to Horder in early August that a compromise had been reached. Drummond had decided to accept the figure "11", as it was now "too late to start fresh arguments about the matter". Macrae had sent the report to the printers. ${ }^{75}$ The final fixing of the formula on protein needs was therefore partly the result of pressure to meet deadlines. The deletion suggested by Sinclair was not made, and Sinclair subsequently sent a note to be inserted in the report. This did not, however, specifically mention the protein figures:

The nutritional allowances adopted by the Committee agree closely with those adopted during the war by the Oxford Nutrition Survey; these were made available to the Committee by Dr. H.M. Sinclair and are shortly to be published. Where there is disagreement in comparable cases between the two, Dr. Sinclair himself prefers the figures of the Oxford Nutrition Survey. ${ }^{76}$

\section{Settling the Controversy: Professional and Institutional Ambitions, and Political Inclinations}

The problem of the level of protein requirements facing the BMA Committee in 1949, it might be suggested, falls into the category of "trans-scientific" questions, as defined by A M Weinberg in 1972. According to Weinberg, such questions are those that can be asked, but cannot be answered, by science. He pointed out that in debates about trans-scientific

\footnotetext{
${ }^{72}$ Wellcome, SA/BMA/G.65, letter from D P Cuthbertson to H Sinclair, 11 July 1949.

${ }^{73}$ Wellcome, SA/BMA/G.65, letter from H Sinclair to J Drummond, 19 July 1949.

${ }^{74}$ Wellcome, SA/BMA/G.65, letter from H Sinclair to J Drummond, 30 July 1949.
}

\footnotetext{
${ }^{75}$ Wellcome, SA/BMA/G.62, letter from A Macrae to Lord Horder, 8 August 1949.

${ }^{76}$ British Medical Association, op. cit., note 5 above, p. 23.
} 


\section{Mark W Bufton, David F Smith and Virginia Berridge}

questions, credibility becomes as important as scientific competence. ${ }^{77}$ This appears to have been the case with regard to the episode described in this paper. None of our scientific actors was really sure what to recommend about protein requirements. None was specially competent to settle the question, and the dispute and its settlement became concerned largely with the credibility of alternative formulations. A Mazur subsequently pointed out that on trans-scientific questions experts might reasonably take any one of several positions. He suggested first that "One's interpretation of ambiguous data is often tied to one's position on the innovation about which controversy exists". Interpretations of ambiguous data are often conditioned by broader, quasi-political interests. Second, he proposed that some experts subscribe to a particular interpretation of ambiguous data simply because they are used to that interpretation and have never questioned it. Third, an expert may take one side or another because a friend has taken it. Coalitions may build and solidify and disagreements become polarized. ${ }^{78}$ The following discussion explores the operation of such factors as credibility, resistance to apparent change and professional and political interests and alliances in the context of this paper.

Credibility was an issue for both the BMA/Advisory Committee on Nutrition conferences in 1934 and the 1947-50 BMA Nutrition Committee, despite the different contexts of the two periods. On both occasions, there appeared to be no question of rejecting the opportunity to publish a statement of protein requirements, ${ }^{79}$ but, in view of the uncertainty of what these were, the credibility of the statement to be published on protein became a major issue.

On both occasions the conflict over protein requirements concerned whether or not the Committee should depart from what was claimed to be, by some actors, firmly established practice. Yudkin, however, was wrong when he claimed that expressing protein requirements or allowances as percentages of energy intake was an entirely new departure. The Advisory Committee on Nutrition's $37 \mathrm{~g}$ of animal protein had come from the rule-of-thumb that 10 per cent of energy should come from protein and half of that (i.e. 5 per cent) from animal protein. At the joint Advisory Committee on Nutrition/BMA conferences there was much discussion about the best means of expressing protein requirements, one option being as a percentage of energy intake. But the verbatim reports of those conferences show that none of the participants could remember where the " 5 per cent rule" had come from. ${ }^{80}$ Likewise, when Yudkin and Yates argued against departing from what they claimed was a generally accepted rule of "1 gram of protein per kilogram body weight", there seems to have been little awareness of the origins of the rule. It had appeared in a paper by the American biological chemist H C Sherman in 1920, and was subsequently adopted by the

\footnotetext{
${ }^{77}$ A M Weinberg, 'Science and trans-science', Minerva: a review of science, learning and policy, 1972, 10: 209-22, 216.

${ }^{78}$ A Mazur, 'Disputes between experts', Minerva: a review of science, learning and policy, 1973, 11: 243-62, 258-9.

${ }^{79}$ It should be noted, however, that there are examples of committees leaving blanks in tables of protein requirements. For example, in 1958, the US Food and Nutrition Board declined to give a figure for
}

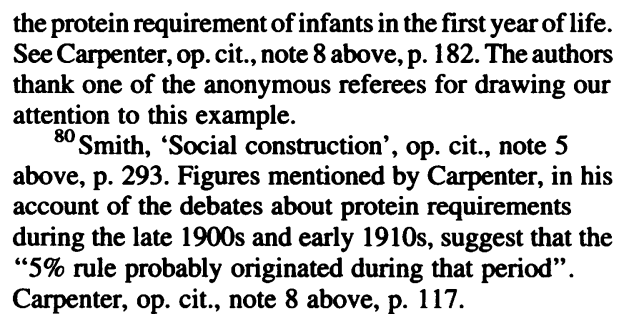

the protein requirement of infants in the first year of life. See Carpenter, op. cit., note 8 above,p. 182. The authors thank one of the anonymous referees for drawing our attention to this example.

${ }^{80}$ Smith, 'Social construction', op. cit., note 5 above, p. 293. Figures mentioned by Carpenter, in his account of the debates about protein requirements during the late 1900 s and early 1910 s, suggest that the " $5 \%$ rule probably originated during that period". Carpenter, op. cit., note 8 above, p. 117. 


\section{Conflict and Compromise in the BMA Nutrition Committee 1947-1950}

Report of the physiological bases of nutrition of the League of Nations (1936). ${ }^{81}$ Similarly, there was nothing new about the idea expressed in Cuthbertson's memorandum of basing dietary requirements upon studies of existing practices.

In 1933-4, calorie as well as protein requirements were matters for dispute, and again, part of the argument was about the wisdom of departing from well-established standards. In 1948-9, however, although statements of calorie requirements according to occupation remained points of contention, the frank admission of uncertainty and the need for more research in this area appears to have provided an effective basis for consensus lasting from the committee meeting in December 1948 until the production of the report. While the draft paragraphs on protein also expressed the scientific uncertainty surrounding protein requirements, the deployment of reasoning based on custom rather than scientific principles made this a promising area for intervention by committee members intent on intervening. No doubt, challenges could also have been made to the figures placed upon individual vitamin or mineral requirements that might have had some consequences for rationing, but the level of the protein requirement was clearly related to the contentious political question of meat rationing. The possible link between their protein recommendation and rationing was certainly a question in the minds of the disputants. ${ }^{82}$

What else can be said of the actions and positions taken by the key participants in this dispute over protein requirements? As for Cuthbertson, having declined membership of the committee because he was required by his employees to concentrate upon animal nutrition, he became involved in its work because he was asked to attend a subcommittee meeting and to submit a memorandum, the predominant tone of which was pragmatic. The Committee called upon his advice again later, following Yudkin's and Yates' interventions, and he was subsequently asked to fix the final figures along with Sinclair. There is no evidence that he was unduly concerned about the precise figures and Sinclair's desire to revise the figures slightly downwards. Since he was under pressure not to become involved in human nutrition, it is not surprising that he seemed disinclined to engage in prolonged controversy on this issue.

The position taken by Yudkin - the view that the proposed "percentage of energy" approach would provide a scientifically indefensible excess of protein for high-energy consumers and a shortage for low-energy consumers-may be seen to be in line with an egalitarian impulse discernible in other contexts. These egalitarian sentiments may have translated into a concern that the "percentage of energy" approach could be used as a rationale for socially divisive demands for extra rations, which would undermine the government's "fair shares" policies. From Yudkin's perspective, basing protein

\footnotetext{
${ }^{81} \mathrm{H}$ C Sherman, 'Protein requirement of maintenance in man and the nutritive efficiency of bread protein', J. Biol. Chem., 1920, 41: 97-109; League of Nations Health Organisation, Report on the physiological bases of nutrition, Geneva, 1936. The origins of the $1 \mathrm{~g}$ per $\mathrm{kg}$ rule were made clear in an editorial in the British Medical Journal in Jan. 1947, 'Protein requirements of adults', Br. med. J., 1947, i: 19-20.

${ }^{82}$ Over forty years later, Yudkin recalled the discussion on protein at the BMA committee meetings.
}

He remembered that in response to the concerns he expressed about possible demands for changes in the rationing system following from the proposed protein requirement figures, Harriette Chick asked whether he would not like a little more bacon to eat? As a Jew, he had a ready reply. Comments made by John Yudkin in response to a paper delivered by David Smith at the Historians and Nutritionists Group seminar, King's College London, 8 July 1992. 


\section{Mark W Bufton, David F Smith and Virginia Berridge}

requirements on the dietary habits of the more affluent, might also be regarded as providing a possibly spurious justification for what, in the prevailing circumstances, might be more properly regarded as excessive consumption.

Yudkin's egalitarian sentiments, and his concern to head-off what he saw as unjustifiable agitation against government policies, were certainly recognizable to other members of the Committee. Macrae bracketed Yudkin with Marrack, whose left-wing leanings have already been indicated. After Yudkin's comments on the section of the report on practical dietetics, one of the recommendations was amended to indicate that the Committee favoured the end of rationing only when this could be "done without detriment to any section of the world population". ${ }^{83}$ Macrae remarked to Horder that this "seems to put off the end of rationing for a century or two". However, he reminded Horder, "the Committee was in a noble and exalted humanitarian mood at its last meeting, led by the only nonChristian in the room, and far be it from me to disagree". Yudkin, who was Jewish, was the person that Macrae referred to. In response to Yudkin's comments, Macrae had added to the report a remark that the Committee was "not to be regarded as accepting as justifiable all the complaints reported to it". This, he thought, "will certainly make Marrack, Yudkin and Co. feel a little less uneasy about our having descended too far towards the level of the British Housewives' League" ${ }^{84}$ The Housewives' League had been responsible for much agitation for a swift end to rationing. Yudkin's political sympathies were therefore recognized by other actors. Yudkin's arguments and alignments have helped us identify Yudkin's politics, for unlike Marrack and le Gros Clark with their well-defined political affiliations, Yudkin was not a well-known activist. It is therefore more appropriate to speak of Yudkin's political "inclinations" rather than "affiliations". ${ }^{85}$ The same is true of Yates' politics.

The explanation for Yates' involvement in the protein dispute is less clear than for Yudkin. Like Yudkin, Yates' opportunities to participate in the work of the committee had been limited. He may have participated in the late challenge to the protein paragraphs partly because, having been co-opted to the food consumption subcommittee for his statistical expertise, he found himself largely uninvolved in its proceedings. The content of Yates' comments certainly suggest an impulse to deploy his special skills in explaining to the nutrition experts the implications of their arithmetical methods. The concern with "fair shares" can also be seen in both Yudkin's and Yates' arguments, suggesting similar political inclinations.

An incident in 1943, when Yates was involved in lobbying the Nutrition Society to produce statements of conclusions of conferences for transmission to government departments, provides some evidence of Yates' political alignment. ${ }^{86}$ On this occasion he had teamed up with his Rothamstead colleague, N W Pirie, and le Gros Clark. Like Clark, Pirie was well-known for his left-wing sympathies. But Pirie is also well-known for his careerlong quest for methods of extracting protein from leaves for human consumption, the

\footnotetext{
${ }^{83}$ British Medical Association, op. cit., note 5 above, p. 97.

${ }^{84}$ Wellcome, SA/BMA/G.62, letter from A Macrae to Lord Horder, 11 Aug. 1949.

${ }^{85}$ Some confirmation of the analysis of Yudkin's politics is provided by an oral history
}

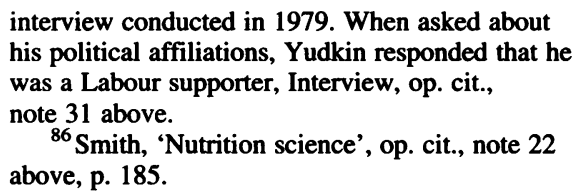
his political affiliations, Yudkin responded that he was a Labour supporter, Interview, op. cit., note 31 above.

${ }^{86}$ Smith, 'Nutrition science', op. cit., note 22 above, p. 185 . 
rationale for which rested upon an assumption of relatively high protein requirements. ${ }^{87} \mathrm{As}$ Yates' comments focused mainly on the potential lack of protein for low energy consumers, there are therefore additional reasons why Yates' association with Pirie might have encouraged his intervention on the protein issue.

In 1934, scientists of the Advisory Committee on Nutrition, outraged that their published dietary standards had been contradicted, soon found themselves negotiating compromise figures with much less eminent representatives of the BMA Nutrition Committee. ${ }^{88} \mathrm{~A}$ similar situation occurred in 1949, after Yudkin and Yates spoke out at the full committee meeting. It was envisaged that Drummond would be able to exert his authority and settle the matter. But, despite his annoyance at Yudkin's and Yates' challenges, Drummond could only arrange an exchange of views and then attempt to compose an acceptable compromise. It was only when a small disagreement between Sinclair and Cuthbertson remained, and the deadline for the completion of the report was pressing, that Drummond took a decision to settle the matter.

Sinclair's immediate reaction to Yudkin and Yates is clarified by considering his own institutional position. Sinclair's professional ambitions had been shattered when, after the War, he had been unable to mobilize sufficient support and finance to establish a full-scale university nutrition department, and now, with a little external funding he was making do with Nissen hut laboratories. Sinclair had been a key member of the nutritional requirements committee, since for most of the nutrients it was his own scales used by the Oxford Nutrition Survey that had been adopted. This helps to explain the offence caused to Sinclair by Yudkin's and Yates' intervention. However, when it came to settling the figures to be entered in the final report, like Yudkin, Sinclair took into account the potential for the Committee's report being used for agitation purposes by people such as Bicknell. But there is no evidence that Sinclair's position arose from the kind of ideological commitments apparent in Yudkin's reasoning. Sinclair's remarks about the possible use of the report being used as the basis for political agitation appear more as distaste for political engagement. This may also explain why, once a figure slightly higher than the one he favoured was adopted, he then submitted only a very bland note of reservation.

This impression is reinforced by Sinclair's attitude towards the informal conferences of nutrition workers that preceded the creation of the Nutrition Society in 1941. These meetings had foundered when Edward Mellanby instructed MRC-supported nutrition workers not to attend after the conferences began to send recommendations to government departments. At this point, John Boyd Orr took the initiative and proposed the formation of a properly constituted scientific society, whereupon Sinclair wrote to Orr commenting that the informal conferences had been useful until they had come to include people more interested in politics than nutrition. He hoped that Orr would institute a "purge" of the group. ${ }^{89}$ In 1934, the joint conference of representatives of the British Medical Association

\footnotetext{
${ }^{87}$ W S Pierpont, 'Norman Wingate Pirie', Biog. Mems Fell. R. Soc. Lond. 1999, 45: 397-415.

${ }^{88}$ Smith, 'Social construction', op. cit., note 4 above.

${ }^{89}$ Smith, 'Nutrition in Britain', op. cit., note 54, above, p. 206. N W Pirie, who spoke about his ideas for
}

extracting protein from leaves at one of the informal conference meetings, may have been one of the politically-minded participants that Sinclair objected to. 
and the Ministry of Health's Advisory Committee on Nutrition reached an agreement on statements of protein and calorie requirements largely because they had no wish to encourage the resurgence of public controversy. Since Yudkin and Sinclair shared a concern about the possibility of the report that they were preparing becoming the subject of public controversy, and Sinclair settled for a very weak note of reservation, in 1949 similar sentiments as operated in 1934 appear to have facilitated the achievement of the published formula. Renewed controversy could cast doubt upon the expert status of the Committee members and damage the credibility of the report as a whole.

\section{Conclusion}

This account and analysis of the protein controversy on the BMA Nutrition Committee in 1949 provides an example of the process by which expert committees on nutrition arrived at recommendations on particularly uncertain questions, questions characterized by Weinberg as "trans-scientific". We have argued that the political inclinations of key actors, and/or professional and institutional ambitions, may contribute to the decisions to intervene in debate, the contents of arguments, and the eventual achievement of compromise. ${ }^{90}$ Given the availability of suitable resources, future research may be able to explore the operation of such factors in the preparation of reports by other expert committees considering dietary requirements and other nutritional issues, and allow further degrees of generalization. ${ }^{91}$

\footnotetext{
${ }^{90}$ It should be noted that we have not suggested that there was or is likely to be any simple correspondence between scientists' politics and views on protein requirements. We have not attempted to link all actors' positions on protein requirements with their political thought. Nevertheless, it is worth noting, that in 1979, when Yudkin, Cuthbertson and Sinclair were interviewed and asked about their political affiliations, their responses varied as follows: Yudkin remarked that he was a Labour supporter, Cuthbertson that he was a Conservative, and Sinclair that he was a Liberal. Interviews, op. cit., notes 26,29 and 31 above.

${ }^{91}$ To date, however, records of other committees of the quality of those available for the 1933-4 BMA
}

Nutrition Committee, the Ministry of Health Advisory Committee on Nutrition, and the 1947-50 BMA Nutrition Committee, have not been recovered. As a result, analyses of the work of the government's Committee on Medical Aspects of Food Policy, for example, have been much broader in focus. See, for example, M W Bufton and V Berridge, 'Post-war nutrition science and policy making in Britain c.1945-1994: the case of diet and heart disease', in Smith and Phillips (eds), op. cit., note 8 above, pp. 207-22; M W Bufton, 'Coronary heart disease versus BSE: characterising official British expert advisory committees', Science and Public Policy, 2001, 28: 381-8. 